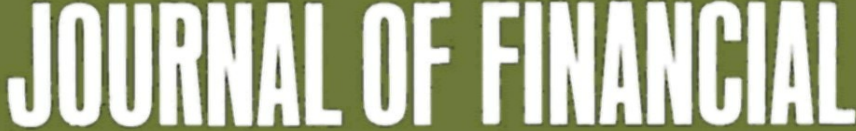

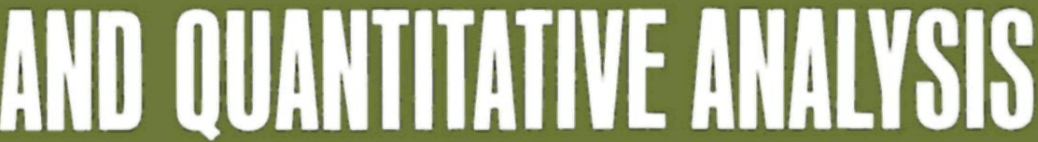

\section{December 1973}

\section{A SPECIAL ISSUE DEVOTED TO FINANCING POLICY}

WILLARD T. CARLETON, CHARLES L. DICK, JR., AND DAVID H. DOWNES

Financial Policy Models: Theory and Practice

\section{BERNELL K. STONE}

Cash Planning and Credit-Line Determination

with a Financial Statement Simulator:

A Cash Report on Short-Term Financial Planning

MANAK C. GUPTA

Optimal Financing Policy for a Firm with

Uncertain Fund Requirements

MARK E. RUBINSTEIN

Corporate Financial Policy in Segmented Securities Markets

\section{ISIK INSELBAG}

Financing Decisions and the Theory of the Firm

WILBUR G. LEWELLEN and GEORGE A. RACETTE

Convertible Debt Financing

\section{ALAN KRAUS}

The Bond Refunding Decision in an Efficient Market

\section{GEORGE M. von FURSTENBERG}

The Equilibrium Spread between Variable Rates and

Fixed Rates on Long-Term Financing Instruments

JAMES C. VAN HORNE

Implied Fixed Costs of Long-Term Debt Issues

GARY I. WAKOFF

On Shareholders' Indifference to the Proceeds Price in Preemptive Rights Offerings 
JOURNAL OF FINANCIAL AND QUANTITATIVE ANALYSIS

A JOINT PUBLICATION

OF THE

GRADUATE SCHOOL OF BUSINESS ADMINISTRATION

UIVIVERSITY OF WASHINGTON

AND THE

WESTERN FINANCE ASSOCIATION

EDITORIAL STAFF

Graduate School of Business Administration University of Washington

Charles W. Haley, Managing Editor

Nancy L. Jacob, Associate Managing Editor

Lynn Lewicki, Editorial Associate

Richard H. Bernhard, North Carolina state Marshall E. Blume, Pennsylvania

Richard S. Bower, Dartmouth William Breen, Northwestern Michael J. Brennan, UBC Myles Delano, Michigan State Thomas R. Dyckman, Cornell Peter A. Frost, Washington Robert C. Goshay, UC, Berkeley Nils H. Hakansson, UC, Berkeley Robert S. Hamada, Chicago Warren H. Hausman, Rochester Frank C. Jen, SUNY, Buffalo
George Kaufman, Oregon Alan Kraus, UBC Henry A. Latané, North Carolina John G. McDonald, Stanford Jacob B. Michaelsen, UC, Santa Cruz Stewart C. Myers, MIT Alfred N. Page, Washington Rogex B. Upson, Minnesota James Van Horne, Stanford George von Furstenberg, Indiana Paul Wells, Illinois Richard R. West, Oregon Robert $L$. Winkler, Indiana 
David Eiteman, President James Wert, Vice President Thomas E. Stitzel, Secretary-Treasurer Charles W. Haley, Editor Scott Bauman Richard V. Cotter John Herzog Vergil Miller David H. Pyle
University of California, Ios Angeles University of Arizona Oregon State University University of Washington University of Virginia University of Nevada Simon Fraser University Sacramento State University of California, Berkeley

INSTITUTIONAL MEMBERS

California State University, Fullerton California State University, Sacramento California State University, San Francisco California State University, Chico Eastern Washington State College Loyola University of Los Angeles Menlo School and College

\section{Alaska Interstate Company}

Pepperdine University Southern California Edison Company

U. S. International University

University of Calgary

University of Southern California Woodbury College

University of California, Los Angeles

Copyright 1974 by the Graduate School of Business Administration, University of Washington.

The Journal of Financial and Quantitative Analysis is published in January, March, June, September, and December by the Graduate School of Business Administration, University of Washington, Seattle, Washington 98195, in conjunction with the Western Finance Association. Second-class postage paid at seattle, washington.

The December issue is a special issue devoted to one topic of interest to the JFQA's readership. The March issue contains selected papers, abstracts of papers, discussants' comments, and the Proceedings of the Western Finance Association meetings.

The views and opinions expressed are those of the authors and do not necessarily reflect those of the Graduate school of Business Administration of the University of Washington nor of the Western Finance Association.

For individuals, the annual subscription rate to the JFQA is $\$ 10.00$ (two-year rate, $\$ 20$; three-year rate, $\$ 28$ ); for firms or libraries, the annual rate is $\$ 15.00$ (two-year rate, $\$ 30$; three-year rate, $\$ 40$ ). Single copies are $\$ 3.00$, except the special issues, the price of which is $\$ 3.50$. Annual subscription rates for individuals and libraries outside the United States (except Canada) are $\$ 11.00$ for individuals (two-year rate, $\$ 22$; three-year rate, $\$ 31$ ) and $\$ 16.00$ for libraries (two-year rate, $\$ 32$; three-year rate, \$43). The fiscal year of the Journal of Financial and Quantitative Analysis begins on January 1 .

Manuscripts and editorial correspondence should be sent to the Managing Editor. Advertising inquiries and books for review should be addressed to the Associate Managing Editor. Correspondence dealing with subscriptions and billing should be addressed: Subscription Manager, JFQA, Mackenzie Hall DJ-10, University of Washington, Seattle, Washington 98195.

Correspondence pertaining to the Western Finance Association should be sent to Professor Les B. Strickler, School of Business, Oregon State University, Corvallis, oregon 97331. 
Financial Policy Models: Theory and Practice . . . . . . . . . . . . 691 Willard T. Carleton, Charles L. Dick, Jr., and David H. Downes

Cash Planning and Credit-Line Determination With a Financial statement

Simulator: A Cash Report on Short-Term Financial Planning . . . . . . 711 Bernell K. Stone

Optimal Financing Policy for a Firm With Uncertain Fund Requirements . $\quad 731$ Manak C. Gupta

Corporate Financial Policy in Segmented Securities Markets . • . . . . 749 Mark E. Rubinstein

Financing Decisions and the Theory of the Firm . . . . . . . . . . . . 763 Isik Inselbag

Convertible Debt Financing . . . . . . . . . . . . . . . . . . . 777 Wilbur G. Lewellen and George $A$. Racette

The Bond Refunding Decision in an Efficient Market . . . . . . . . . . 793 Alan Kraus

The Equilibrium Spread between Variable Rates and Fixed Rates on Long-

Term Financing Instruments . . . . . . . . . . . . . . . . . . . . 807 George $M$. von Furstenberg

Implied Fixed Costs of Long-Term Debt Issues . . . . . . . . . . . . . 821 James $C$. Van Horne

On Shareholders' Indifference to the Proceeds Price in Preemptive

Rights Offerings .................... 835 Gary I. Wakoff

Index to Volume VIII - 1973 . . . . . . . . . . . . . . . . . 837

Announcements . . . . . . . . . . . . . . . . . . . . . . . 842

Reprint from June 1973 Journal of Financial and Quantitative Analysis . • 846 
Title of Publication:

Frequency of Issue:

Location of office of Publication:

Location of General Business office:

Publisher:

Editor:

Extent and Nature of Circulation:

Total Number of Copies Printed:

Paid Circulation:

Sales through dealers and carriers, street vendors, and counter sales

Mail subscriptions

Total Paid Circulation

Free Distribution by Mail and Other Means: samples, complimentary, and other free copies Copies distributed to news agents but not sold

Total Distribution

Office Use, Leftover, Unaccounted Total
Journal of Financial and Quantitative Analysis

Five times per year (January, March, June, September, December)

Mackenzie Hall, University of Washington Seattle, Washington 98195

Mackenzie Hall, University of Washington Seattle, Washington 98195

Graduate School of Business Administration, University of Washington

Charles $w$. Haley

\begin{abstract}
Average Number of Copies Each Issue (preceding 12 months)
\end{abstract}

1700

0

1400

1400

100

0
1500
$200^{*}$
1700

Actual Number of Copies, September 1973 Issue

1650

*Most of these are later sold by mail order.

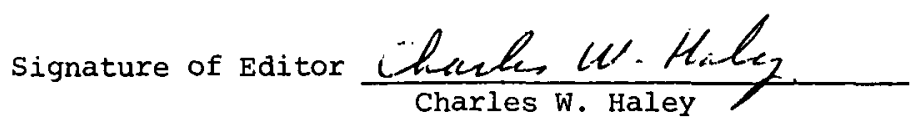

